\title{
INTERMODALITY - TRANSPORTATION SOLUTION FOR GLOBAL TRADE
}

World trade has been growing at an average rate which is considerably greater than the growth rate of GDP (Gross Domestic Production). Policies aimed at the reduction of tariffs and quotas have led to an increase in the bilateral trade flows between countries. Increasing global trade also means that opportunities of transportation are growing. The efficient transportation solutions for global trade really offer demand for transport market by sea because of its satisfaction in long-distance routes as well as mass quantity of transported freight. Increasing business relations of two continents EU and Asia (especially ASEAN plus 3 named APT) $)^{1)}$ are obviously creating potential trends for transportation network and corridors. One of the very important sea transport routes between ASEAN + 3 and EU can link up the Danube river. While traditional transportation used to separate individual modes of transportation, intermodalism creates unbroken door-to-door transport chains.

\section{Global trade and modalities of transport}

Nowadays, a number of important developments affecting international flows of goods and international logistics are: globalization (globalization of the production process), the empowered consumer (growing competition in international trade, time-based competition), power shift in the supply chain (supply chain management strategies), technology (growth of computerization, electronic data interchange „EDI“ and global e-commerce) and deregulation (elimination of quotas or embargoes and freight rates is more flexible according to the laws of supply and demand).

The globalization of world trade not only increases the significance of international logistics but also has an impact on the behaviour of all those who are directly or indirectly involved in organizing this logistical process. First and foremost, there is a growing trend towards providing an integral door-to-door intermodal transportation services. At the same time, efforts are also made to sell additional value-added logistics services. Why can we confirm that Intermodality must become transportation solution for global trade?

According to the definition of OECD, intermodalism implies the use of at least two different modes of transport in an integrated manner in a door-to-door transport chain. The intermodal concept is therefore an integral part of the global logistics chain concept. Intermodal transportation allows each mode to play its role in building transport chains which overall are more efficient, cost-effective and sustainable. Thus it provides a solution that combines individual modes of transport and enters into a global

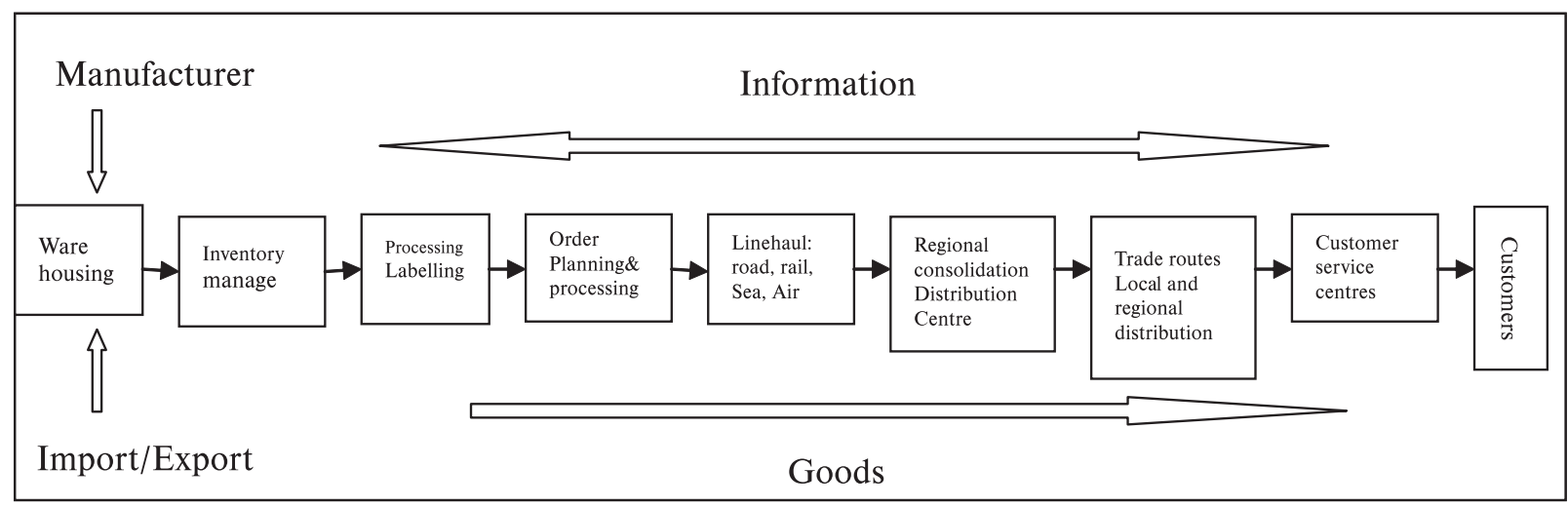

Source: Review of development in transport and communications in ESCAP-2001, United Nations Fig. 1 Supply chain services: A contemporary Western view of logistics

\footnotetext{
* H. Hansenova, Ho Thi Thu Hoa

Department of International Business, Faculty of Commerce, University of Economics in Bratislava, Slovak Republic

1) ASEAN +3 (APT) includes 10 Asia South East Nations (Brunei, Cambodia, Myanmar, Laos, Singapore, Thailand, Vietnam, Malaysia, Philippines, Indonexia) and South Korea, Japan, China.
} 
logistics chain which is not necessarily the result of each mode of transport performed individually. It can be confirmed that intermodal transportation is the smart transport combination.

Providing an integral door-to-door intermodal transportation is a typical example of a logistics chain approach (shown in Fig. 1), how one considers the totality of costs from the point of raw material to the destination of consumption.

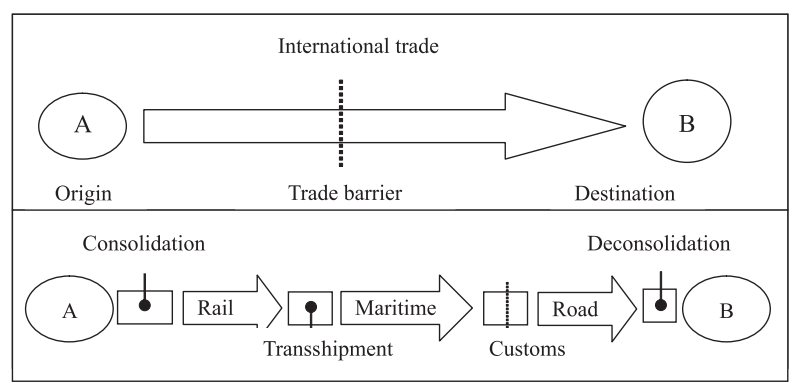

Source: www.people.hofstra.edu/geotrans

Fig. 2 International trade and Transportation chains

Transportation can be carried out in many ways and forms. Transportation techniques or transport modalities are considered as manner of road, rail, inland water, ocean shipping, air, pipeline. The choice of suitable transport modes is depending on several factors as characteristics of goods, transport distances, requirements of shippers, etc ...

In contemporary transportation, shippers are more interested in the end result from transportation than with using a specific mode of transportation. So long as the shipper's service requirements are satisfied, they are essentially indifferent as to the mode used to provide the transportation. ${ }^{2)}$ The pattern of these transportation services is model of door-to-door intermodal transporta-

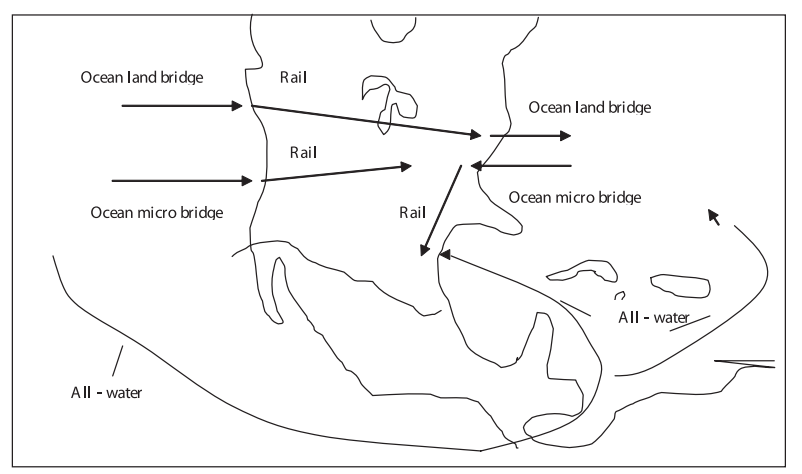

Source: The Management of Business Logistics, AMACOM 2002, p.153 Fig. 3 Types of International Intermodalism

\footnotetext{
2) International Logistics, p. 431.

3) Review of Maritime 2004.

4) Review of Maritime 2004, see chapter 4.
}

tion - using different transport modalities with preferably: one organiser, one document, one responsibility, one price and in unbroken chain transport (shown in Fig. 2).

A prime example of international intermodalism is a land bridge which occurs on the trade route between Japan and Europe. The all-water route takes anywhere from the twenty-eight to thirty-one days. If the shipment travels by water from Japan to Seattle (ten days), then by rail to New York (five days), and by water from New York to Europe (seven days), we have a total shipping time of approximately twenty-two days (shown in Figure 3).

\section{Trade boom and the demand of transportation between ASEAN + 3 and EU}

On routes from EU to APT and on opposite, demand of transportation is not only in cargoes movements but also in passenger transport and tourism (shown in Fig. 4). EU people are discovering the natural material resources, business opportunities in new dynamic markets and tropical landscapes of Asia as well as APT countries.

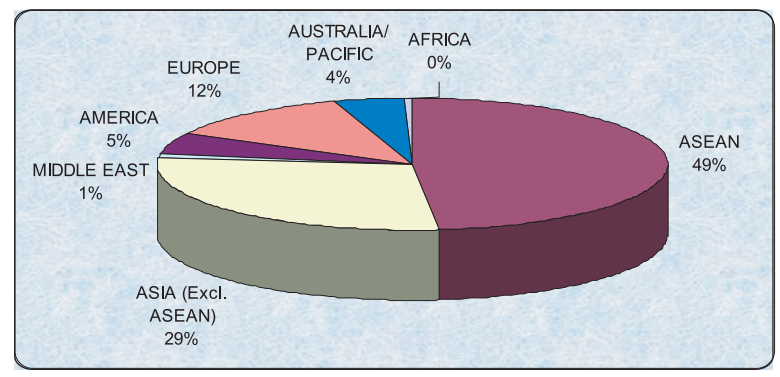

Source: www.aseansec.org/tour_stat

Fig. 4 Major market share by region of international visitor arrivals to ASEAN (2004)

On the Europe-Asia trade route, the transportation from Asia increased by 10 times the increase in the opposite direction. ${ }^{3)}$

The coming cargoes from APT countries need sustainable transport system with cost effective and efficient operation. The event of quota elimination in garment imports from China, Vietnam and other countries in ASEAN perfectly contributes in increasing cargo exports from APT to EU members. Liberalization of trade without quota barriers forecasts necessary demand on transportation and services. The movements of cargo exports from APT to EU such as garments, shoes, electronic components, agricultural and aquatic products, furniture and flows of cargo imports of APT from EU as industrial equipment, chemical products, finished automotive products absolutely need the efficient solution for transportation of cargo between two areas ${ }^{4}$. However, unbalance in merchandise trade (shown in Fig. 5) between the EU and APT will bring challenges for shipping carriers. 


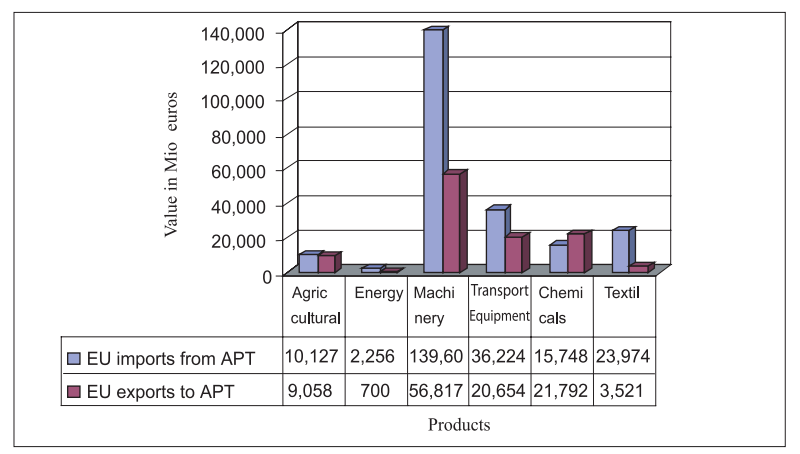

Source: EUROSTAT, 2004

Fig. 5 EU25 merchandise trade with APT by product (2004) (Mio Euros)

While considering statistics of cargo flows along major trade routes as following: Asia - USA, Asia - Europe and USA - EU, we can realize the fact that cargo flows on route Asia - EU and Asia - USA have two or three times larger than that on route USA - EU (shown in Fig. 6), for example, Western-Central China exported over 132,000 TEU to Europe.

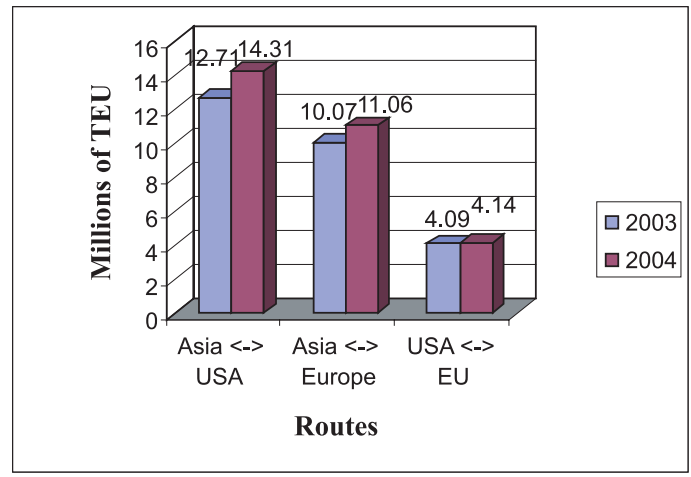

Source: Review of Maritime, 2004

Fig. 6 Cargo flows along major trade routes (millions of TEU)

APT is one of the most dynamic integrated economic zones which includes China and Vietnam - two economies with the highest growth rate of GDP in the world. Almost countries in APT have export - oriented economic policies, especially such as export value ratio to GDP of Vietnam achieved $57.4 \%$, of China reached $34.5 \%$. Therefore, EU - 25 enlargement with new ten potential markets will benefit for foreign trade activities of APT.

\section{Possibilities of freight transportation on routes between ASEAN + 3 - EU}

The expansion in trade has benefited transportation on routes connecting between ASEAN +3 and EU. Intermodality will be the

\footnotetext{
5) The Management of Logistics Business, p. 163.

${ }^{6)} \mathrm{http}$ ///europa.eu.int/scadplus/leg/en/s13000.htm
}

best solution for this situation. So which possibilities are considered for choice of corridors and combination of transport modalities on routes Asia - Europe and ASEAN + 3 - EU?

In 2004, at Kiev they discussed about use of rail transit capacities for intermodal freight transport for passage from China to Europe via Kazakhstan, Turkmenistan, Iran, Russian Federation, Belarus, the Caucasus States, Ukraine and Turkey.

The Trans-Siberian Railway is one of the most attractive transport routes in the world. This railway line running over 10,000 kilometres, one of the world's longest lines, leads from Russia's western border to its Pacific ports in East Siberia. Built in the years 18951916, the line runs via Moscow, Ryazan, Samara, Chelabinsk, Omsk, Novosibirsk, Krasnoyarsk, Irkutsk, Chita and Khabarovsk to Vladivostok. Its branch lines lead towards Kazakhstan. Uzbekistan, China and other countries.

However, the sea transport routes have more cost-efficient because they are very well established, accounting for two-thirds of all international movements ${ }^{5}$. There are several transport corridors Asia - Europe which concentrate on shipping by sea

From 2000, Russia, Iran and India signed an agreement in St. Petersburg laying out a vision for a North-South Transport Corridor. The corridor stretches from ports in India across the Arabian Sea to the southern Iranian port of Bandar Abbas, where goods then transit Iran and the Caspian Sea to ports in Russia's sector of the Caspian. From there, the route stretches along the Volga River via Moscow to northern Europe. On the $13-15^{\text {th }}$ May 2004 Turkey, Russia and Central Asia Transport, Maritime and Railway Ministers met at regional Caspian Transport Summit in Istanbul. Ministers discussed a variety of intermodal transportation and logistics issues including the goods flows, capacity and direction of energy transportation from the Caspian region to Europe via the Black Sea as well as the potential of maritime transport between Central Europe and Black Sea region via the Danube.

The world economy is proving record price of fuel (increasing price from USD 40 until USD 60 per oil barrel). The fluctuation of fuel price has seriously impacted on transportation market and price of goods. The requirements of environment preservation and greenhouse effect have influenced on the pattern of choice modes of cargo transport. While road or rail transport have flexible advantages in short - distance routes, maritime transport is main transport mode which take part in long - distance routes as well as satisfy demand of mass cargo quantity shipping. Therefore, sea transport has become the major transport mode for cargo movement on route EU - ASEAN + 3 and has to be a link connecting to another transport mode to establish integrated door-to-door intermodal transport chain. When transport network is planned connecting sea transport and inland water way between Asia and EU, it will contribute in development of maritime and river trade of EU countries, such as Slovakia. Until now, over $90 \%$ of EU external trade and some $43 \%$ of its internal trade goes by sea; more than 1 billion tonnes of freight a year are loaded and unloaded in EU ports. ${ }^{6)}$ Maritime companies belong to European Union nationals control one third of the world fleet, and some $40 \%$ of EU trade is carried on vessels controlled by EU owners. 
One of the very important sea transport routes between ASEAN +3 and EU can be described as follows:

The shipments from APT -> Strait of Malacca via Port of Singapore (the second largest sea port in the world) $->$ Indian Ocean $\rightarrow>$ Red Sea via Suez canal -> Mediterranean Sea -> Black Sea -> sea ports of Europe -> inland waterway intra EU via Danube river.

The strait of Malacca, linking the Indian and Pacific Oceans. More than 50,000 vessels per year transit the Strait of Malacca. With Chinese oil imports from the Middle East increasing steadily, the Strait of Malacca is likely to grow in strategic importance in coming years.

The Danube River is the second longest river in Europe. ${ }^{7)}$ The Danube has always been an important route between Western Europe and the Black Sea. One reason for this is the fact that it is the only major European river to flow west to east. The source of the river is located in the Black Forest area of Germany, from there, it flows about 1,770 miles to the east.

There are many important cities that the Danube flows through. They include Passau, Vienna, Budapest, Bratislava, Belgrades. With the aid of canals, the Danube is connected to the Main, Oder, and Rhine Rivers. This waterway connects the North and Black Seas. For commercial transportation, the Danube is extremely valuable.

Transport network between ASEAN + 3 countries and EU states will establish more effective routes for shipping cargoes from APT to EU west countries through means of sea transport between Pacific and Indian Ocean as well as inland waterway en route intra EU via Danube river. This network will also contribute to development of maritime and river trade of EU countries, such as Slovakia. It is no doubt that these situations are creating the opportunities for cargoes movements between two continents-especially development in shipping cargo, promoting for routes by sea transport between two continents and inland waterway intra EU. The biggest advantages of these corridors are to reduce transit time and lead lower cost, and that is very good news both for transport operators and customers.
Intermodality is also the effective combination of transport modes: sea - air, sea - rail, rail - road, etc. Therefore, it is very necessary to improve infrastructure of rail, road transports as well as intermodal transportation terminals. In Europe, the integration of transport routes into the Trans European Networks and the development of alternative transport corridors including the North-South corridor from Russia and North Eastern Europe to Iran have created linking corridors to Asia. Europe and Asia have also been discussed with inter-regional parties involved in the projects including the European Commission, European Commission for Energy and Transport (Trans-European Networks), International Road Federation, International Union of Railways, United Nations and the Organisation for Railway Co-operation.

\section{Conclusion}

The combination of different modes of transport to offer better links has been known as intermodality. Transportation has derived from the demand of cargo and passenger movements. The global trade has been increasing quickly , cargo flows are moving to and from dynamic economies. ASEAN and EU have gradually become essential trade partners, economic co-operation and trade relations are also major issues between these areas. However, increasing trade requires efficient means of transport for shipping cargo smoothly and cost-effective. How can we link modes of transport into unbroken transportation chain with the aid of modern informatics technique, EDI and logistics to serve for trade purposes on route ASEAN - EU? The answer is intermodality, this transportation solution will promote for developing maritime transport between ASEAN and EU as well as inland waterway transport en route intra EU via Danube river (contributing on commercial activities of cities along Danube river included Bratislava).

This article is one of the solutions in research project VEGA No $1 / 3761 / 06$.

\section{References}

[1] BALÁŽ, P. a kol: Medzinárodné podnikanie, Sprint, Bratislava, 2005, ISBN: 80-89085-51-2.

[2] HANSENOVA, H., HOA, H. TH. TH., HLAN, T.: Effect of intermodal transportation for exportable and global marketing of companies, proceedings of 8th international conference EUROKOMBI-INTERMODAL 2005 - development of combination transport after EU enlargement, Zilina - Slovakia, 14-15/06/2005, pp. 69-73.

[3] HOA, H. TH. TH.: Influences of EU southeastwards expansion on ASEAN + 3 trade and transport network, international scientific conference in the framework of VEGA project 1/2640/05 „European Union - the enlargement towards southeastern", University of Economics, Bratislava 11/11/2005.

[4] WOOD, D.F., BARONE, A. P., MURPHY, P. R., WARDOW, D. L.: International Logistics, AMACOM, 2002.

[5] Review of Maritime 2004, chapter 4.

[6] COYLE, J. J. et al.: The management of Business Logistics, South Western Thomson, 2003.

[7] www.people.hofstra.edu/geotrans

[8] //europa.eu.int/scadplus/leg/en/s13000.htm

${ }^{7)}$ Along its way, the Danube flows through countries (Germany, Austria, Slovakia, Hungary, Croatia, Serbia and Montenegro, Bulgaria, Romania, Ukraine) 